\title{
AN INVESTIGATION INTO THE STATUS OF PROJECT MANAGEMENT IN SOUTH AFRICA
}

\author{
M-L. Barry ${ }^{1}$ and L. Uys ${ }^{2}$ \\ ${ }^{1}$ Graduate School of Technology Management \\ University of Pretoria, South Africa \\ marielouise.barry@up.ac.za \\ ${ }^{2}$ Synchrony Logistics (Pty) Ltd \\ Gauteng, South Africa \\ leon@synchrony.ih.co.za
}

\begin{abstract}
This research investigated the status of project management in South Africa. A total of 81 respondents participated. It was found that internal stakeholders are more likely to have similar opinions on project success than external stakeholders; and that project managers use optimistic reporting because they do not want to appear to let the project stakeholders down. The top five factors for achieving project success are teamwork, cost management, project planning, scope management, and leadership. The six most important indicators of project success are client/customer satisfaction, project team skill level, senior management buy-in, communication or project reporting, scope management, and on-time project delivery.
\end{abstract}

\section{OPSOMMING}

Hierdie navorsing ondersoek die status van projekbestuur in Suid-Afrika. Een-en-tagtig respondente het deelgeneem. Dit is bevind dat interne rolspelers meer geneig is om dieselfde opinies te hê oor projeksukses as eksterne rolspelers; en dat projekbestuurders optimisties is in verslaggewing omdat hulle nie die projekrolspelers wil teleurstel nie. Die top vyf faktore om projeksukses te haal is spanwerk, kostebestuur, projekbeplanning, bestekbestuur, en leierskap. Die ses belangrikste indikators van projeksukses is kliënttevredenheid, vaardigheid van die projekspan, inkoop van senior bestuur, kommunikasie of projekverslaggewing, bestekbestuur, en om die projek betyds af te lewer. 


\section{INTRODUCTION}

Project management has existed for thousands of years - since the pyramids were built. Only in the $20^{\text {th }}$ century, however, did project management become a subject of serious study and optimisation [1].

The first indication that a systematic approach was required in planning public works projects was given by the UK Institute of Civil Engineers in a 1944 publication. This was followed by the use of project management by the United States Navy in the Polaris programme in the 1950s, and by the use of project management principles by the National Aeraonautics and Space Administration (NASA) in the Apollo programme [1].

Andersen et al. 0 state that "project work in developing and emerging economies is complicated and unpredictable". They made this observation when comparing Norwegian and Chinese projects.

The question arises: Is project management practice in South Africa, which is a developing economy, different from project management practice elsewhere in the world?

\section{RESEARCH OBJECTIVES AND METHODOLOGY}

The purpose of this paper is to present the results of a study conducted into the current status of project management practice in South Africa in the $21^{\text {st }}$ century. The specific objective was to determine project management indicators in the following areas:

- Project perceptions in terms of project success, status reporting (whether pessimistic or optimistic), and the abandoning of projects before completion.

- $\quad$ Project management status in terms of whether project management processes and methods should change, and the most important success factors for projects.

- $\quad$ Project measurement in terms of the importance of certain indicators for project success, and the use of evaluation tools in organisations.

- The South African context as it relates to the differences between international and South African project management practice.

The research methodology consisted of four phases: a literature survey, survey instrument development, data gathering, and data analysis. The literature survey concentrated on project success, project management success (including project maturity), and the future of project management. The survey instrument development was informed by the findings of the literature survey, the data was gathered electronically using the Survey Monkey online survey tool, and the data was analysed using statistical techniques.

\section{LITERATURE REVIEW}

Various sources have highlighted that project reporting and perspectives play a major role in defining project status, and thus determining their success or failure. Belassi and Tukel [3] mention that rapid changes in the business environment will also affect the success factors of projects in the future. Standing et al. [4] state that non-formal project evaluation causes wrong reporting on the outcome of projects through inaccurate perspectives on resources.

Snow, Keiland and Wallace [5] support this by stating that both optimistically and pessimistically biased reporting impacts on project status. The 'mum effect' (trying not to convey bad news), impressing senior management, building 'slack', and 'blame-shifting' are some reasons for biased reporting mentioned in Snow et al. [5]. For this reason, the method of reporting, whether pessimistic or optimistic, and the perceptions of various stakeholders regarding project success were investigated. The rate of project abandonment was also investigated. 
Belassi and Tukel [3] acknowledge that it is impossible to list all the critical factors that affect project outcomes. So they group them in a new framework of four related areas: project-related, manager- and team-related, organisation-related, and external, environment-related (Figure 1).

The advantage of this framework is that it readily identifies success factors and highlights the relationships between these different group factors. Standing et al. [4] declare that user support and involvement, project management and leadership, planning, executive and sponsor buy-in, total organisation, and team buy-in and commitment will ensure successful projects.

Cannon [7] asserts that project size, technology experience, and the "degree of specificity of end result" influence project success.

Lyytinen and Hirschheim [8] point out four major types of failures: correspondence, project, interaction, and expectation. Myers and Larsen [9] report that it is difficult to gauge a project's success, since the various stakeholders change their views over time as to the extent of the project's success or failure.

Pinto and Kharbanda [10] claim that the following actions guarantee project failure: ignoring the environment, trying to attain leading-edge technology, not planning for alternative solutions, blaming others, blocking ideas, the absence of feasibility studies, no admission of failure, no post-failure reviews, over-management of team and project managers, not understanding project trade-offs, weak project leadership, and allowing politics and power play.

Project success differs from project management success: the latter may influence project success, but is unlikely to prevent project failure [11].

Patanakul and Milosevic [12] have found that a higher standardisation of project management tools leads to higher project success. The four standardised project management factors they describe are standardising project organisation, the information management system, project management metrics, and the project culture.

Winter and Smith [13] indicate that directions for future research in project management should include theories on the complexity of projects and project management, projects as social processes, value creation as the prime focus of projects, broader conceptualisation of projects, and practitioners as reflective practitioners.

In a study carried out by Crawford et al. [14], the two main project management journals International Journal of Project Management and Project Management Journal - were used to identify the status of project management research from 1994 to 2003 . The results showed that "relationship management, resource management, time management, cost management and risk management all display consistent significance throughout the study period. However, by contrast, finalization, scope and marketing tend to either be ignored by writers on project management or identified as not being of significance. Project evaluation, improvement and strategic alignment are increasing in their significance to the field. Evidence also suggests that the significance of quality management and interpersonal issues has peaked, and that while these issues have previously been of interest to writers in the field, this interest is waning." 


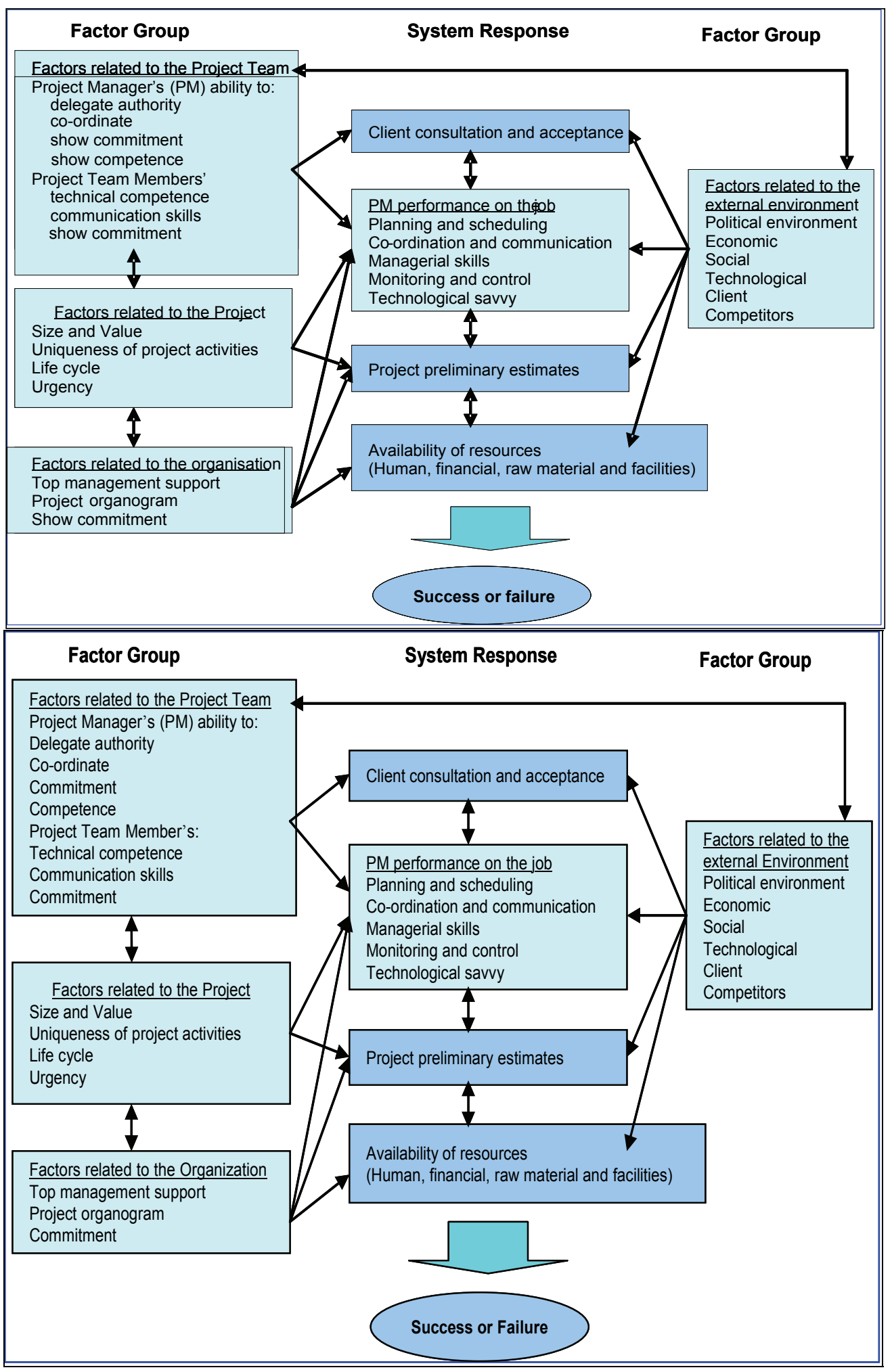

Figure 1: Critical success/failure factors in projects Source: Belassi and Tukel [3] 
An assessment needs to be done to determine the level of project management in an organisation, The maturity of project management in organisations can be measured using many tools. For the purposes of this study, the tools mentioned below will be evaluated to determine how often they are used in the South African setting.

Slevin and Pinto [15] developed a project implementation profile (PIP) that could be used to assess and determine the success or failure of projects. The PIP assesses projects in terms of project plan, resources, ownership, justifiable case, expertise, clear and specific goals, and top level support. Belout [15] argues that the PIP does not evaluate the training, motivation, experience, and commitment of project managers as independent variables which implies that human resource management is still an issue in the evaluation of project status. The project evaluation scheme (PEVS) was used by Andersen et al. [0] to evaluate projects.

The organisational project management maturity model (OPM3) [17] was developed by the Project Management Institute to enable organisations to assess their level of project maturity against the industry's best practices.

Zwikael [18] used project management planning quality (PMPQ) to evaluate projects in different industries, and found that the model is a valid and reliable means of measuring the quality of project planning. Project managers in the service industry, making use of $P M P Q$, have a better quality of planning than those in the maintenance or production industries. The overall quality of a project is measured with a PMPQ model, based on the planning process of a project and analyses of it as defined by the project management body of knowledge (PMBOK).

\section{SURVEY INSTRUMENT DEVELOPMENT}

The survey instrument was a questionnaire implemented using Survey Monkey (www.surveymonkey.com) for electronic distribution and analysis of the results. Most of the expected respondents had access to e-mail; using this online tool ensured data integrity. Survey Monkey captures all responses in a database, thus eliminating human error.

The purpose of the survey was to determine the opinions of various parties on the current state of project management in South Africa. The first part of the survey collected demographic information on the respondents. This section included the continent of each respondent's birth, countries in which a respondent's projects were currently being executed, industry sector, role or responsibility of the respondent, number of activities on the work breakdown structure for typical projects, resource size of projects, typical project budget, number of years' project management experience, and number of years' international project management experience.

The second section dealt with project perceptions, and especially with the stakeholders' perception of success in the last project they were involved in, and why project managers use optimistic or pessimistic reporting. Respondents were also asked whether projects are abandoned before completion. For these questions, respondents had to respond to certain statements on a Likert scale with the following graduations: strongly disagree, disagree, neutral, agree, and strongly agree. Management status was measured by asking respondents to respond, using the same Likert scale, whether in their opinion the project management methods and processes in their organisation should change. Respondents were asked to select those project success factors that they thought were important by selecting as many as were applicable from the list shown in Figure 2.

In the third section of the survey, the respondents were asked to indicate the importance of project success indicators using a Likert scale with the following graduations: very important, important, neither important nor unimportant, important, and very important. 
Respondents were also asked to indicate whether the various evaluation tools discussed in the literature survey had been used in their organisations.

The last section dealt with the South African context. Respondents were asked whether, in their opinion, there was a difference between South African and international projects in terms of success. The respondent were also asked to indicate where South African projects differed from international projects, using a Likert scale graded from strongly disagree to strongly agree.

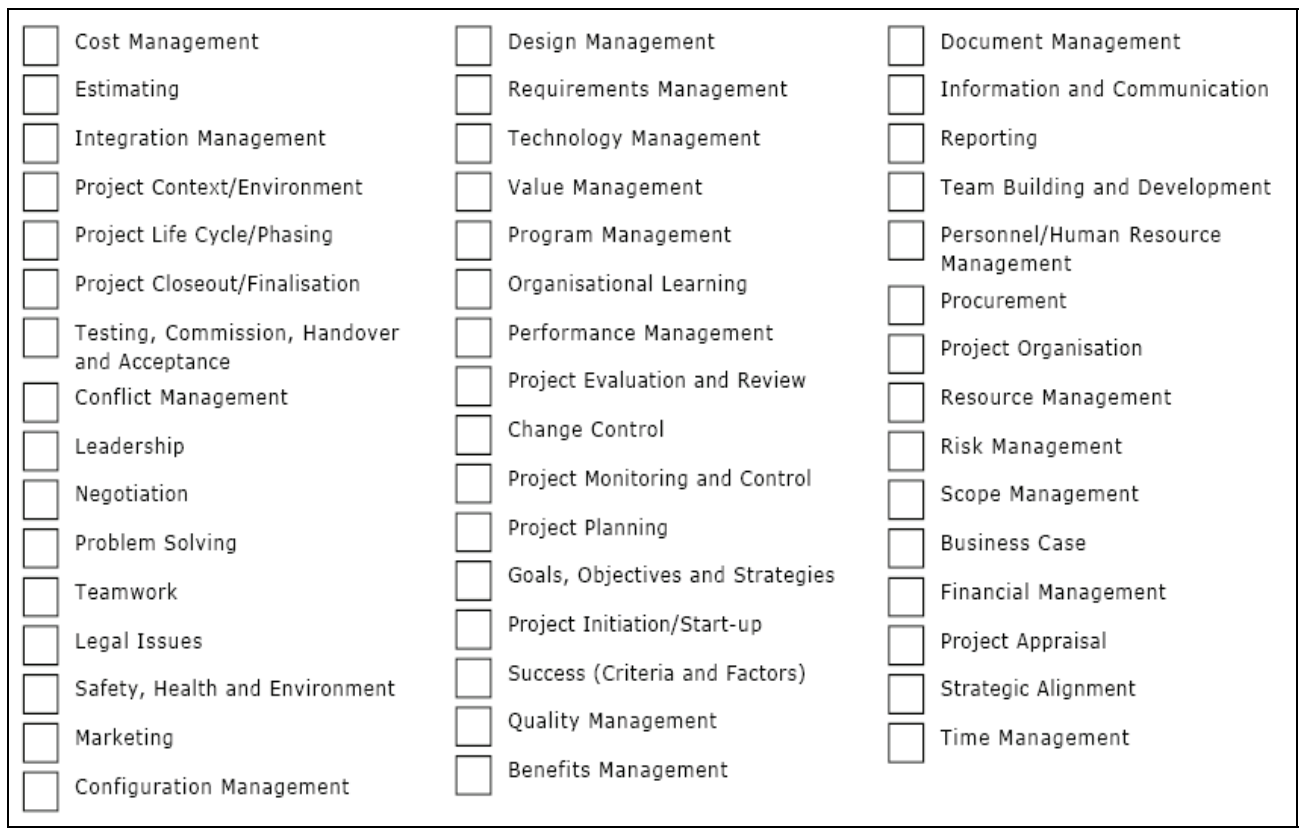

Figure 2: Project and project management success factors summarised from the literature

\section{DATA GATHERING}

Students with Project Management Masters degrees were targeted as well of members of the Project Management Institute Special Interest Group. This is a population size of about 2,500 . Snowball sampling was used.

The aim was to achieve a confidence level or reliability of at least $90 \%$, with a confidence interval or accuracy of at least $10 \%$ if the same study were repeated with a different sample. According to Table 1, in order to obtain reliability of $90 \%$ with an accuracy of $10 \%$, a minimum of 68 respondents is required.

Required sample size:

To determine the effective sample size that corresponded to the response rate of the participants, the following formula given by Page and Meyer [19] was used:

$$
\text { Margin of error }=2 \sqrt{\mathrm{p}(1-\mathrm{p}) / e}
$$

where $p$ is the expected proportion and e the effective sample size.

In the simple random sample design, the design effect (d) is equal to 1 and the effective sample size $(\mathrm{n} / \mathrm{d})$ is equal to the sample size $(\mathrm{n})$. Applying the formula to the sample design selected, with a margin of error equal to $10 \%$, an effective sample size of 68 is the result. 
This implies that, from a sample group, at least 68 participants need to reply to all questions in the questionnaire.

\begin{tabular}{|c|r|r|r|}
\hline \multirow{2}{*}{$\begin{array}{c}\text { Confidence } \\
\text { Interval }\end{array}$} & \multicolumn{3}{|c|}{ Confidence Level } \\
\cline { 2 - 4 } & \multicolumn{1}{|c|}{$\mathbf{9 0 \%}$} & $\mathbf{9 5 \%}$ & \multicolumn{1}{c|}{$\mathbf{9 9 \%}$} \\
\hline $1 \%$ & 6765 & 9604 & 16576 \\
\hline $5 \%$ & 271 & 384 & 663 \\
\hline $10 \%$ & 68 & 93 & 166 \\
\hline $20 \%$ & 17 & 24 & 41 \\
\hline
\end{tabular}

Table 1: Sample size

Source: Page and Meyer [19]

A link to the survey was created in Survey Monkey and sent via e-mail to forty respondents. The respondents were asked to send the survey to as many other project managers as possible. The respondents were required to complete the survey on the internet.

\section{RESULTS}

A total of 128 responses were collected. Of that total, 81 respondents completed all the questions, and only these respondents were used to evaluate the results. The results support a confidence level and reliability of greater than $90 \%$ and accuracy of at least $10 \%$.

The distribution of the respondents' continents of birth was as follows: $87 \%$ Africa, $6 \%$ Europe, $6 \%$ North America, and 1\% Asia. The distribution of the respondents' project execution locations was as follows: 79\% South Africa, 15\% United Kingdom, and 19\% United States of America. (More than one response was allowed.) It was noted that $58 \%$ of the respondents were involved in project execution outside of South Africa.

Figure 3 indicates the business sector in which the respondents' projects were executed. Information Technology (39\%), Transportation and Logistics (13\%), Engineering and Mining $(13 \%)$ and Consulting and Services $(11 \%)$ make up $76 \%$ of the results.

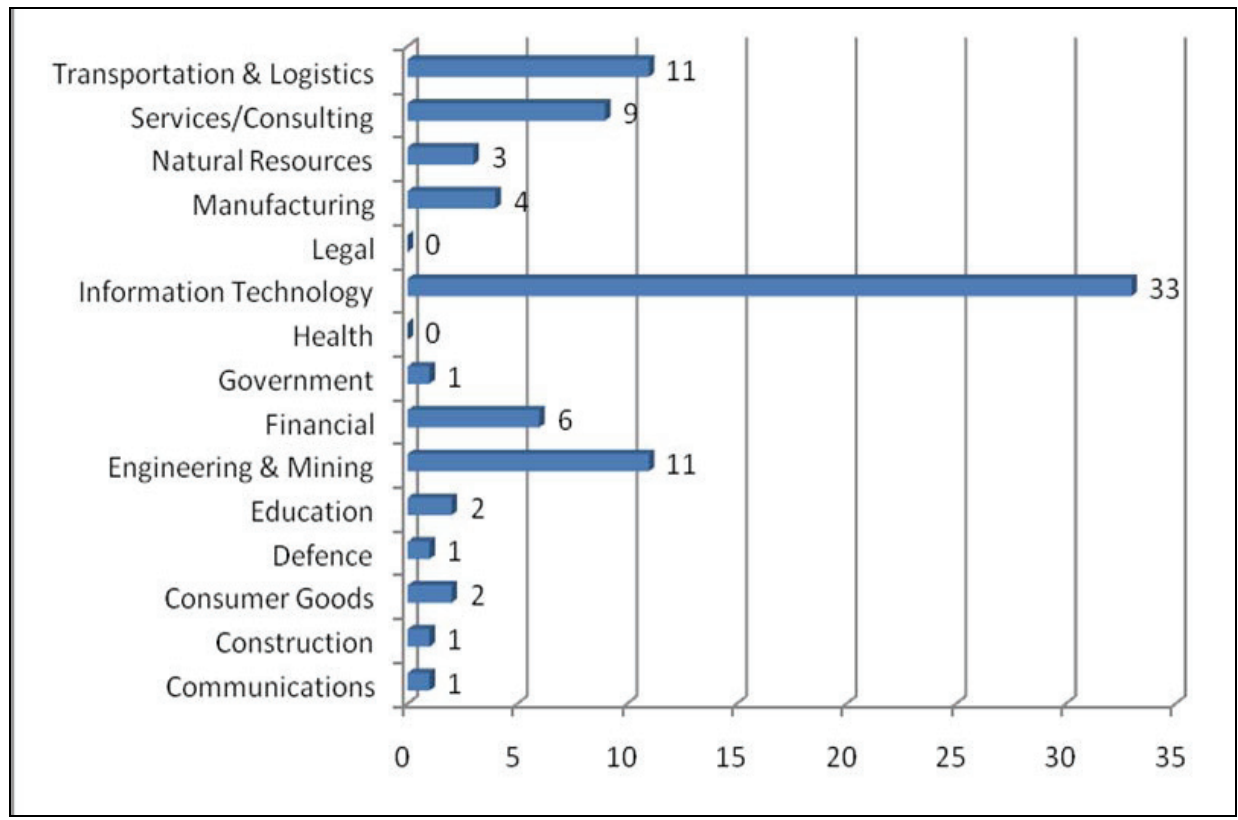

Figure 3: Respondents' business sectors 
In a project environment, project personnel can sometimes have various roles and responsibilities. For this reason respondents were asked to indicate the role in which they spent the majority of their time. The majority of respondents $(27$, or $33 \%)$ mostly fulfilled the role of project managers, followed by $13(16 \%)$ as team leaders and $11(14 \%)$ as team members. This indicates that $63 \%$ of the respondents were directly involved in project execution. The distribution of project roles is shown in Figure 4.

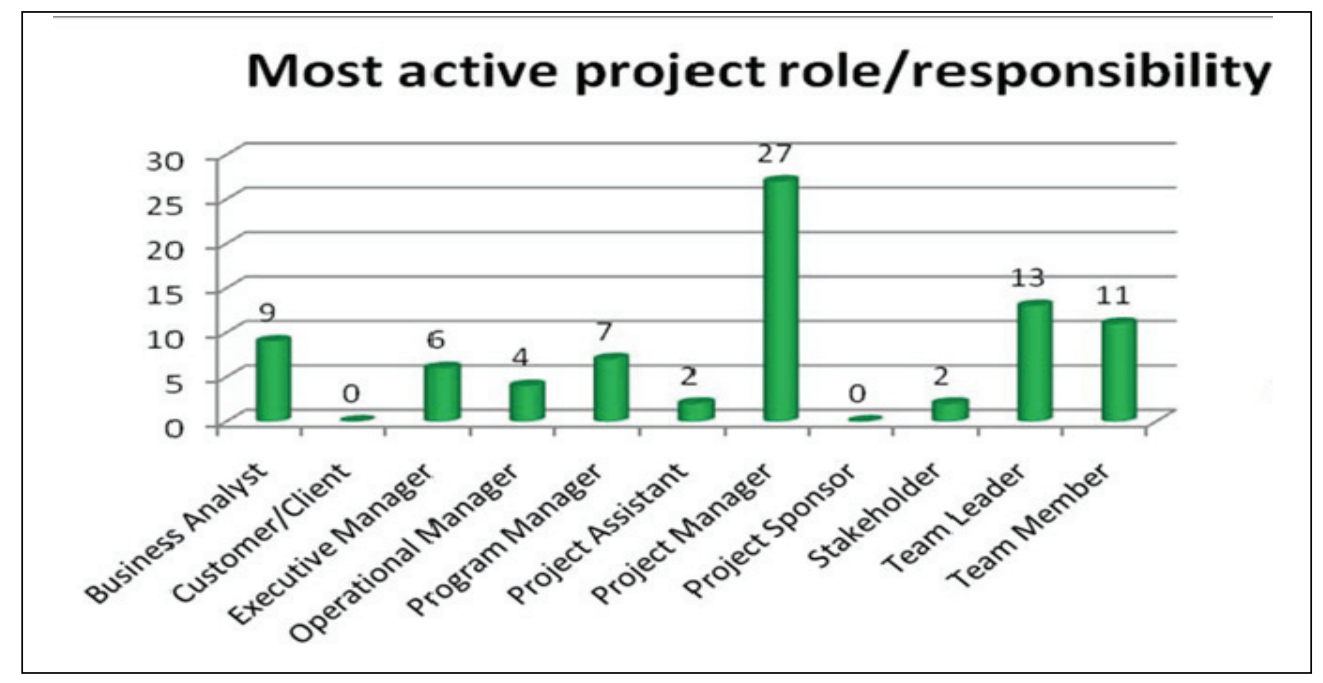

Figure 4: Project role or responsibility where respondents spend the majority of their time

Figure 5 shows the typical size of the projects that respondents work on. This indicates that this research is applicable to small, medium, and large projects.

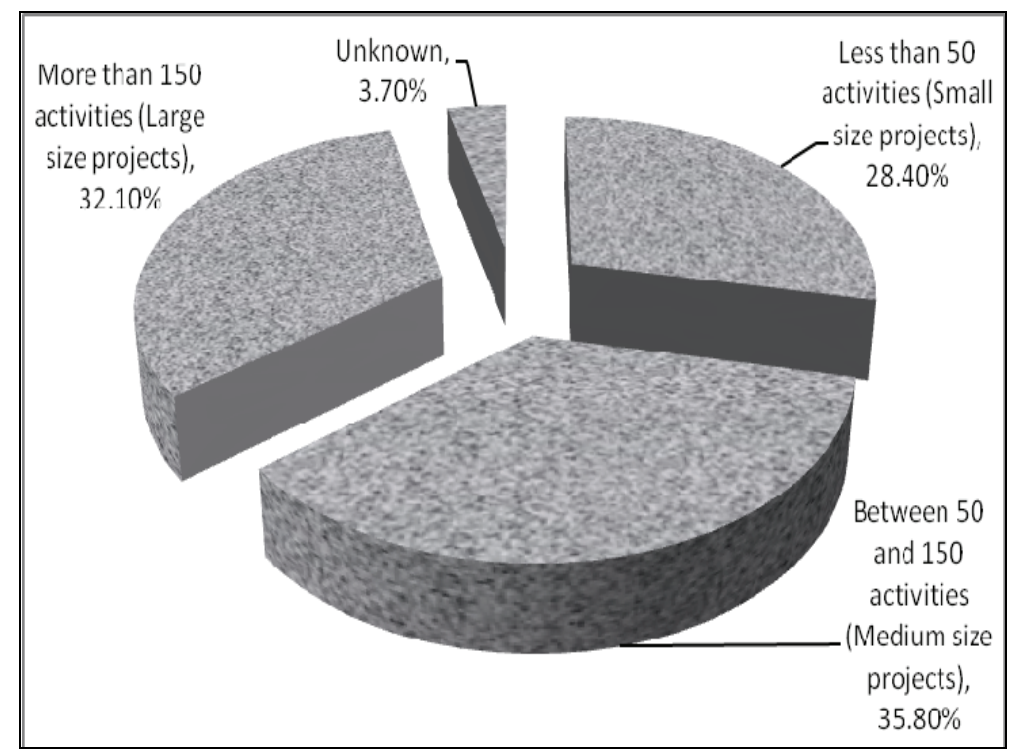

Figure 5: Typical project size in terms of number of work breakdown structure activities 
In terms of team size, the majority of respondents $(42 \%)$ indicated that they worked on project teams with fewer than 10 members; 35\% had between 10 and 50 team members, and $21 \%$ worked on teams of more than 50 members. The majority of respondents $(52 \%)$ worked on projects with budgets exceeding R1 million, with $82 \%$ of all the projects exceeding a budget above R100,000.

The respondents' average project management experience/exposure was 6.7 years. On the other hand, respondents had an average of only 1.7 years' international project management experience. This suggests that answers on local project management were based on experience, whereas answers on international project management may be conjectural.

The results of the respondents' perceptions on the success or failure of the last project that they had worked on is shown in Figure 6. It can be seen that the client or customer seems to have a lower perception of success than the stakeholders within the organisation.

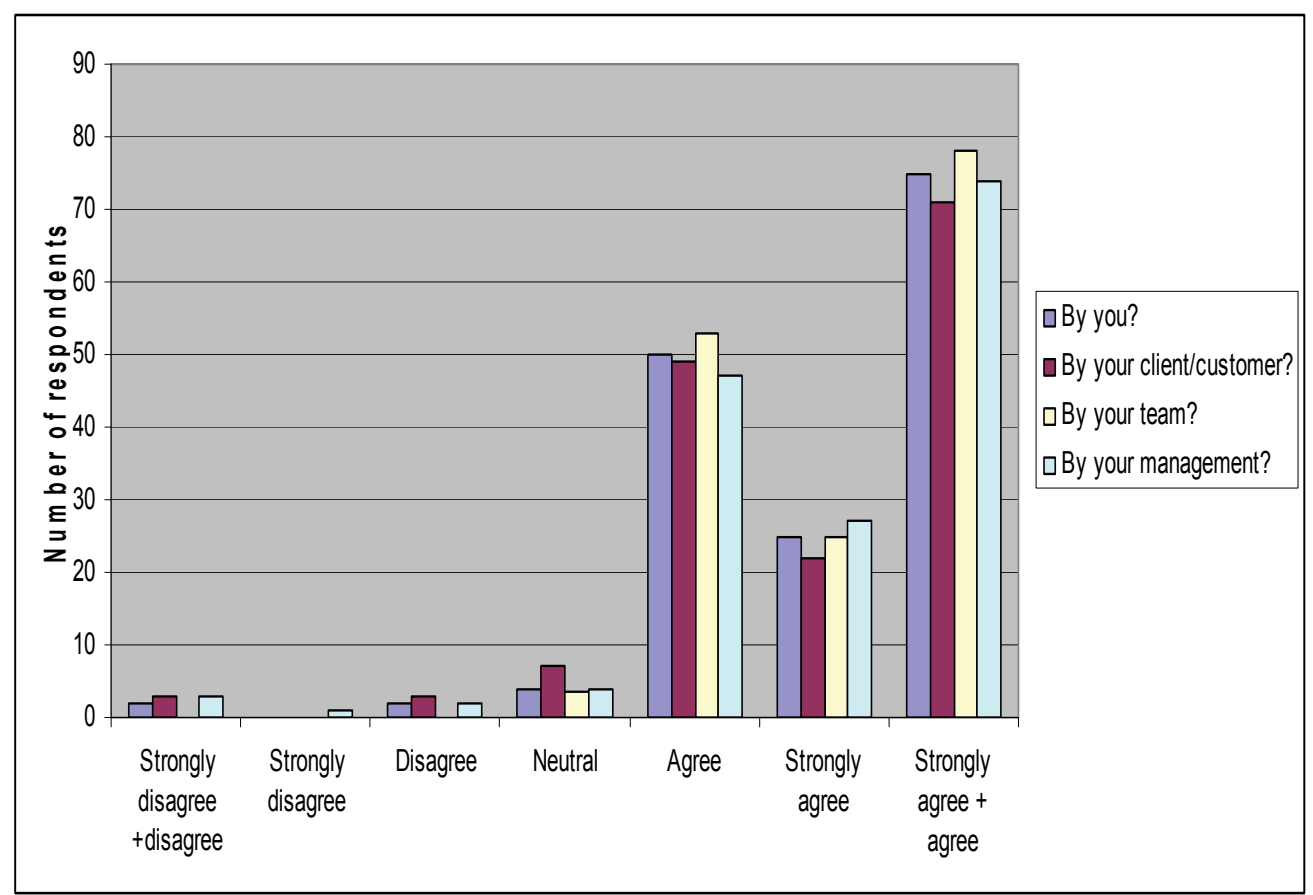

Figure 6: Respondents' perception of the success of their last project

When asked about optimistic project reporting, the main reason selected by $63(78 \%)$ of the respondents was that project managers use optimistic reporting because they do not want to let the client, customer, team, or management down (Figure 7). Management perception and pressure do not seem to influence optimistic reporting behaviour.

The results of the question about pessimistic reporting are shown in Figure 8. They indicate either that pessimistic reporting is not used, or that the correct reason for pessimistic reporting has not been identified, as the respondents mostly chose 'strongly disagree' or 'disagree' about the validity of these reasons. 


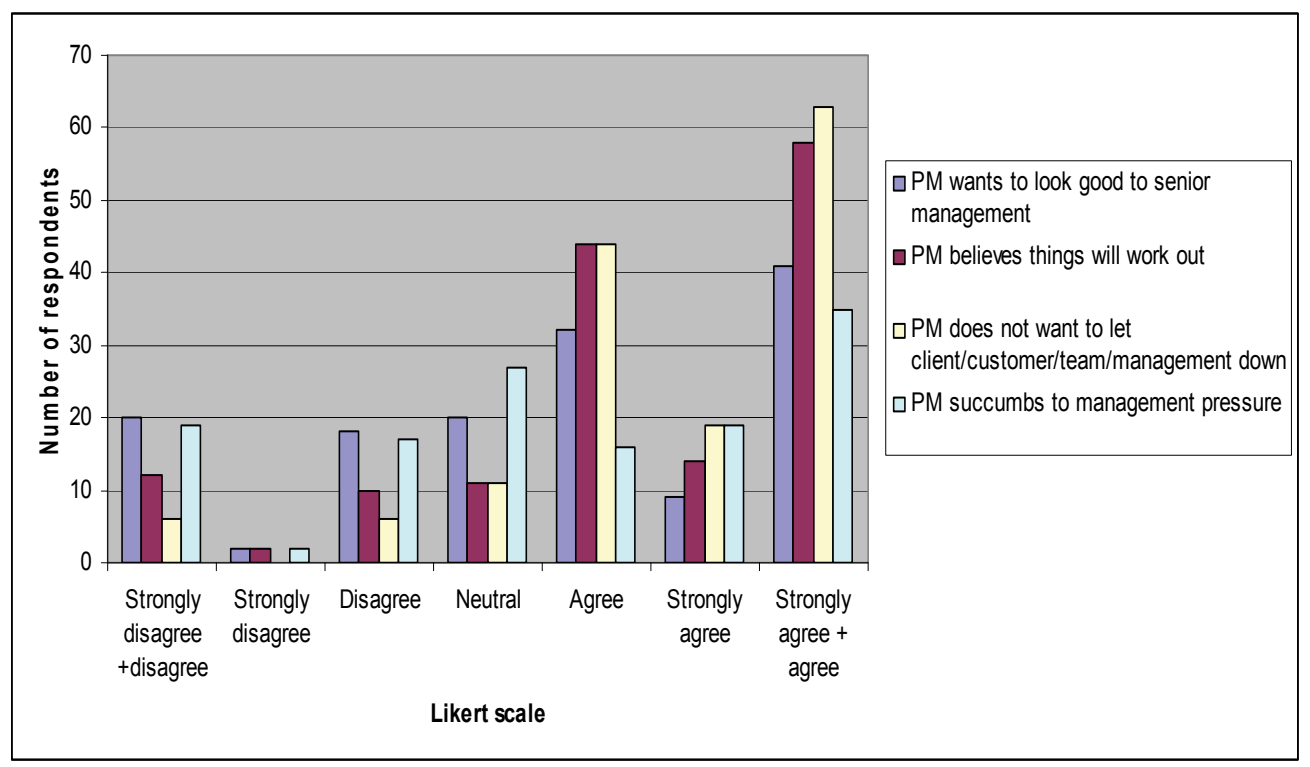

Figure 7: Reasons for optimistic reporting

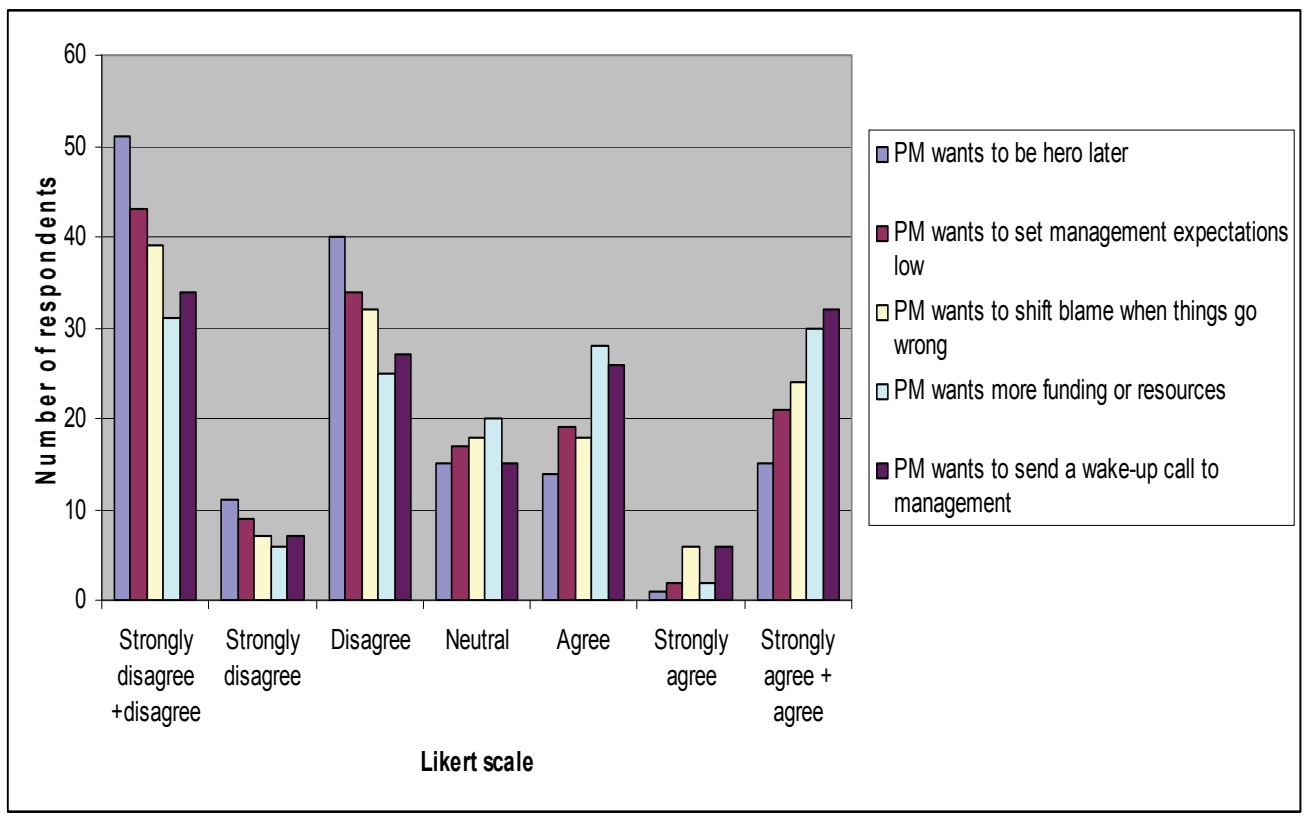

Figure 8: Reasons for pessimistic reporting

Respondents either disagreed or strongly disagreed $(84 \%)$ that the majority of the projects in their organisations are abandoned before completion.

In response to the first question about project management status, $69 \%$ of the respondents either agreed or strongly agreed that the method that their organisations currently use to manage projects needs to change. The distribution of responses is shown in Figure 9. 


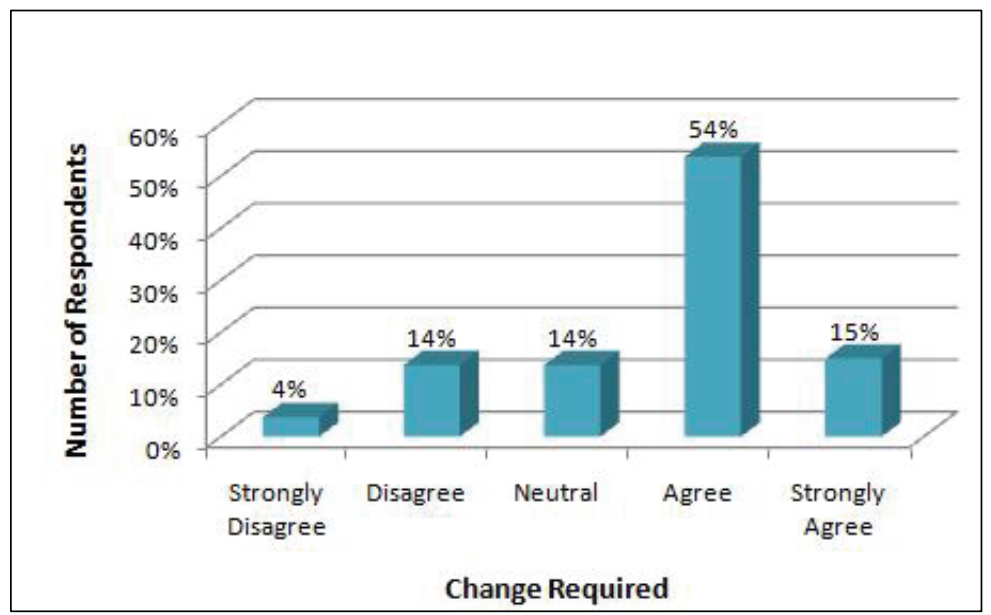

Figure 9: Distribution of responses about the need for change in project management methods

In the project management status question, respondents were asked to select from a predetermined list those project success factors that they thought were important. Respondents could select as many factors as they thought were applicable. The results are shown in Figure 10.

According to the respondents, the top five factors for project success are teamwork, cost management, project planning, scope management, and leadership. This relates to the findings of Crawford et al. [14] in terms of research in the field of project management and in terms of cost management, but not the other factors - especially scope management, which is declining, according to Crawford et al. [14]. This could be an indication that in practice these topics are important in South Africa. Further research may be needed.

Respondents were then asked to rate the importance of project success indicators. The results are shown in Figure 11. The respondents rated the following indicators as the six most important: client/customer satisfaction, project team skill level, senior management buy-in, communication or project reporting, problem scope management, and project delivery on time.

The last two of the six most important indicators form part of the traditional 'iron triangle' of project success: on brief, on budget, and on time. The other four factors can all be highlighted with arrows in the framework developed by Belassi and Tukel [3] (Figure 12).

In terms of project management evaluation tools, the results were disappointing, as the majority of recipients indicated that evaluation tools had not been used in their environments. The non-use for each tool is as follows: PEVS has not been applied in $86 \%$ of the respondents' environments, followed by OPM3 at $86 \%$, then PIP at $80 \%$, and PMPQ at $78 \%$. (Refer to the literature survey for a detailed description of each of these tools.) 


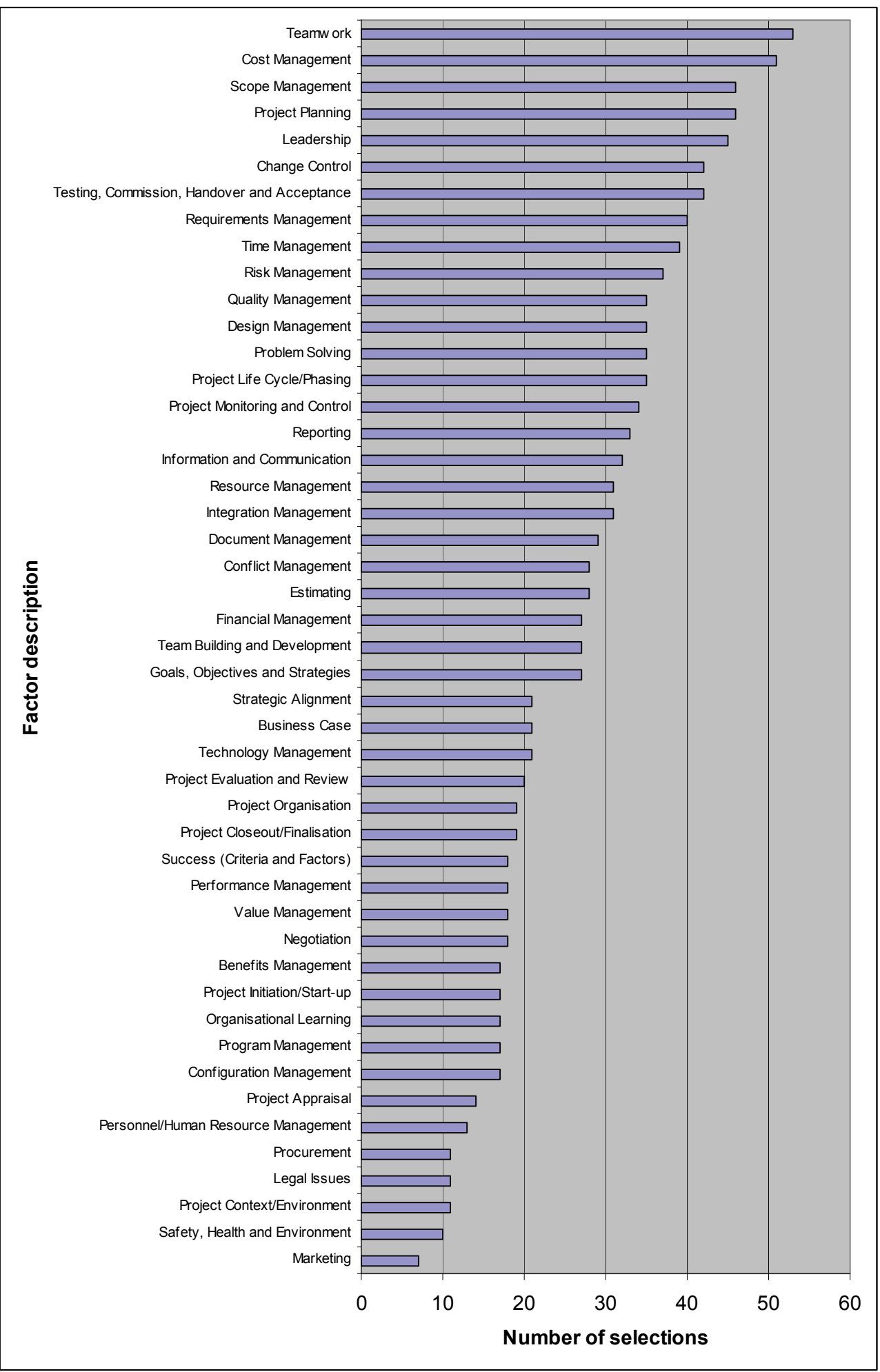

Figure 10: Prioritised list of project success factors 


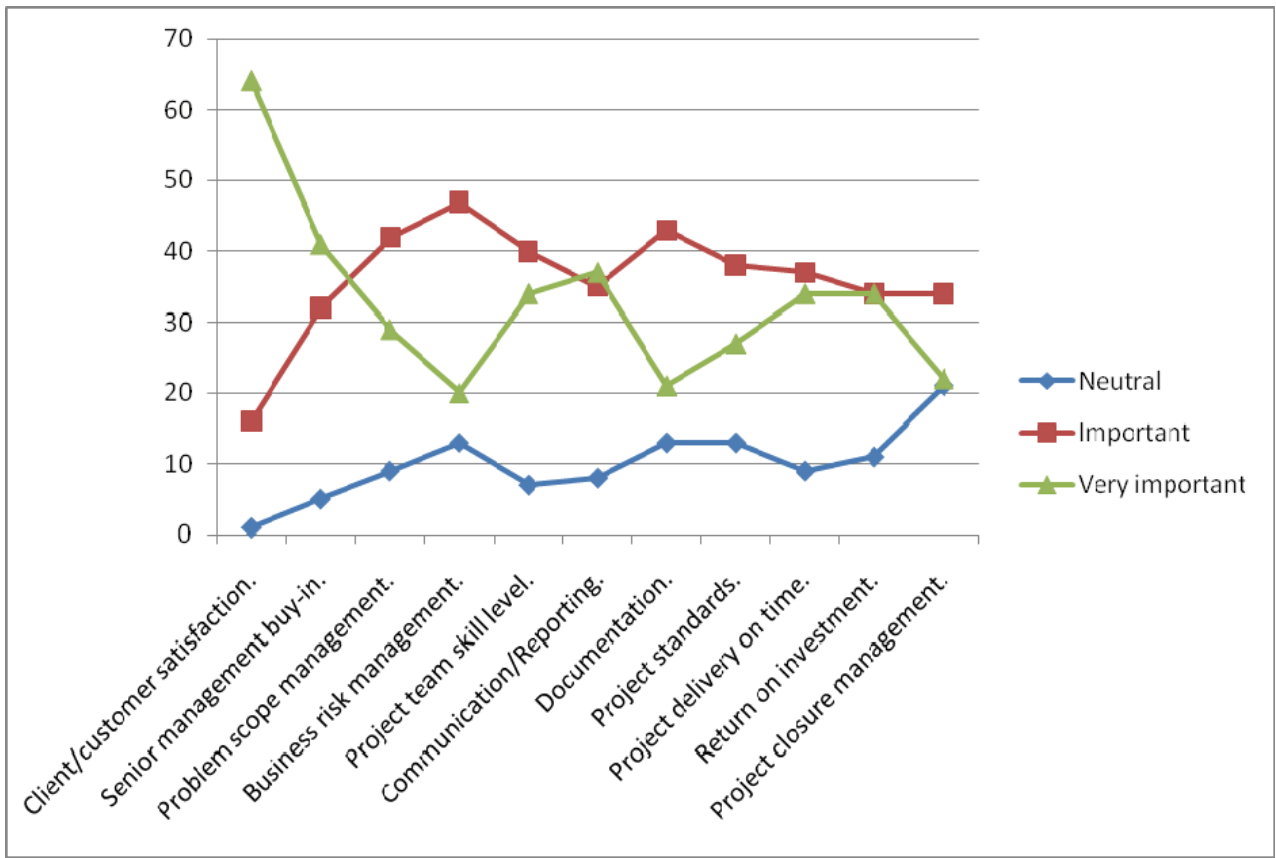

Figure 11: Rating of importance of project success indicators

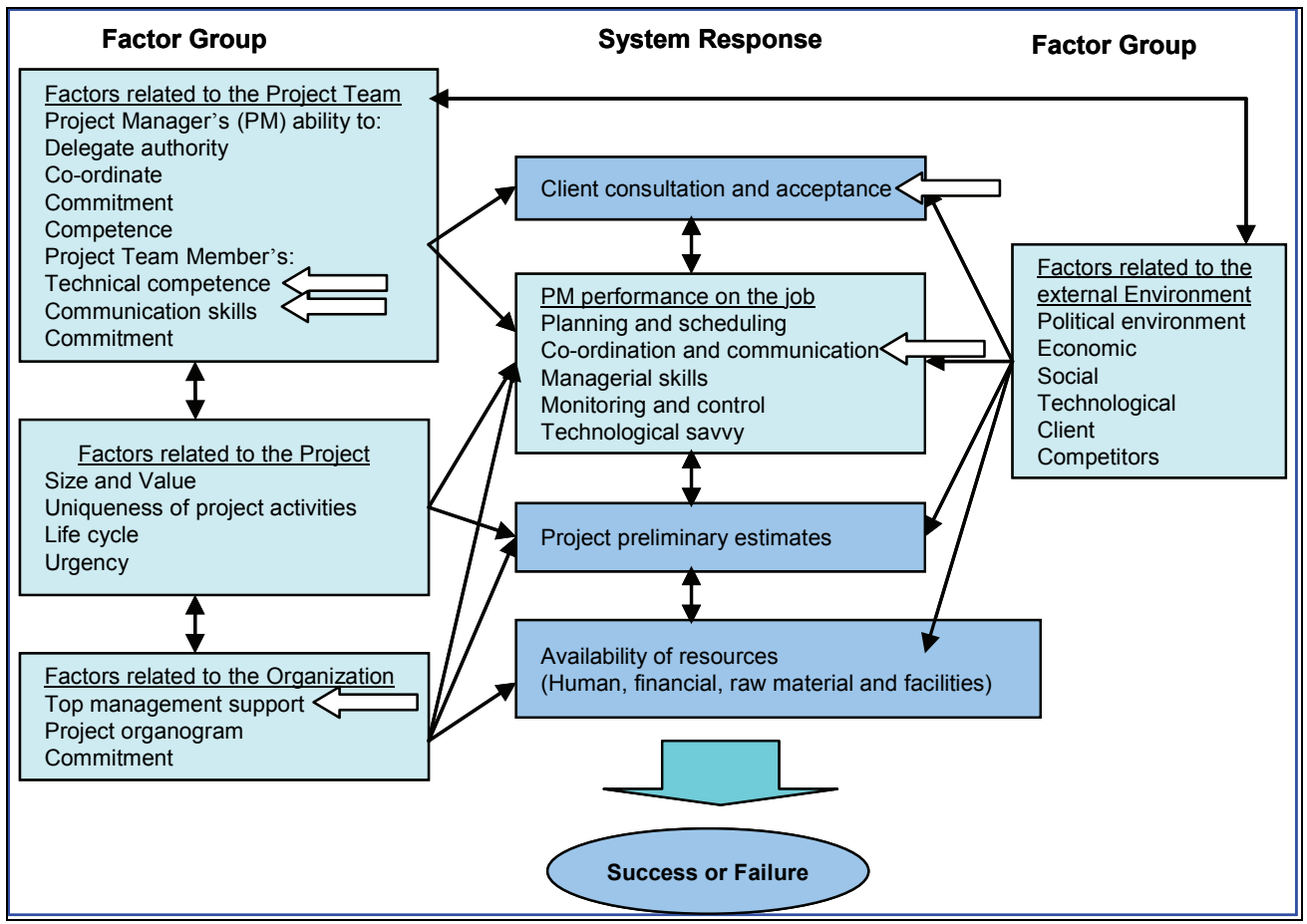

Figure 12: Critical success/failure factors in projects, with results from this study highlighted by arrows (Source: Belassi and Tukel [3]) 
There was no consensus amongst respondents in terms of whether there were differences between South African and international projects (Figure 13). It can be seen that the percentage of those who think that there are differences $(39 \%)$ is slightly higher than those who think there are no differences (31\%) and those who don't know (30\%).

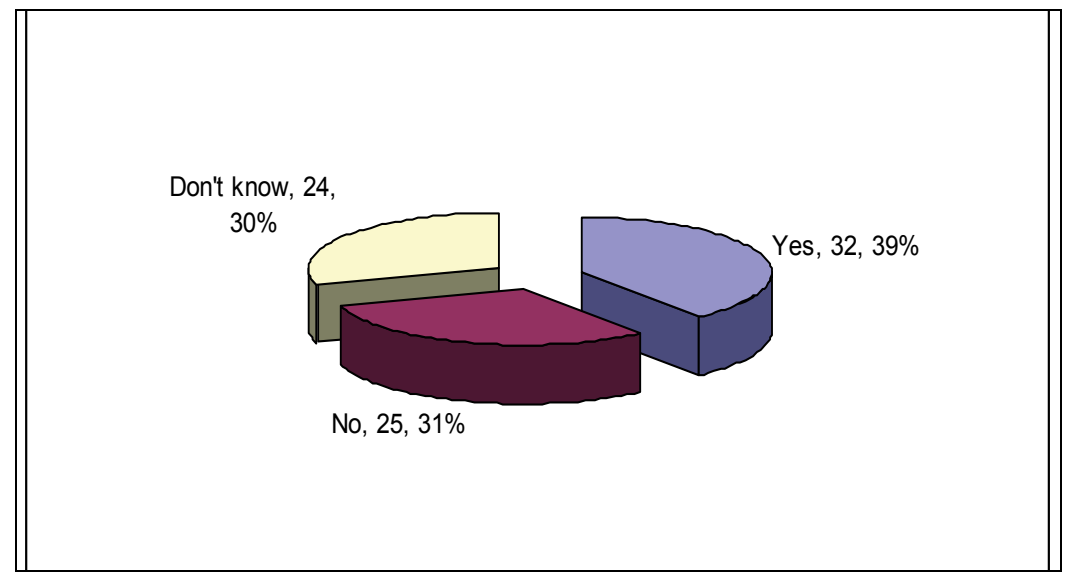

Figure 13: Opinion on differences between South African and international projects

In an effort to identify the differences between South African and international projects, respondents were asked to rate six factors. The results of the rating are shown in Figure 14. The only two factors that scored above $50 \%$ in terms of influencing the difference between South African and international projects were resource skill level (59\%) and social/ political processes $(51 \%)$. This seems to indicate that, in the opinion of the respondents, there is not much difference between factors that affect project management in South Africa when compared with international projects. The sample size is not large enough to show a statistical difference for the various business sectors. This should be investigated in future studies.

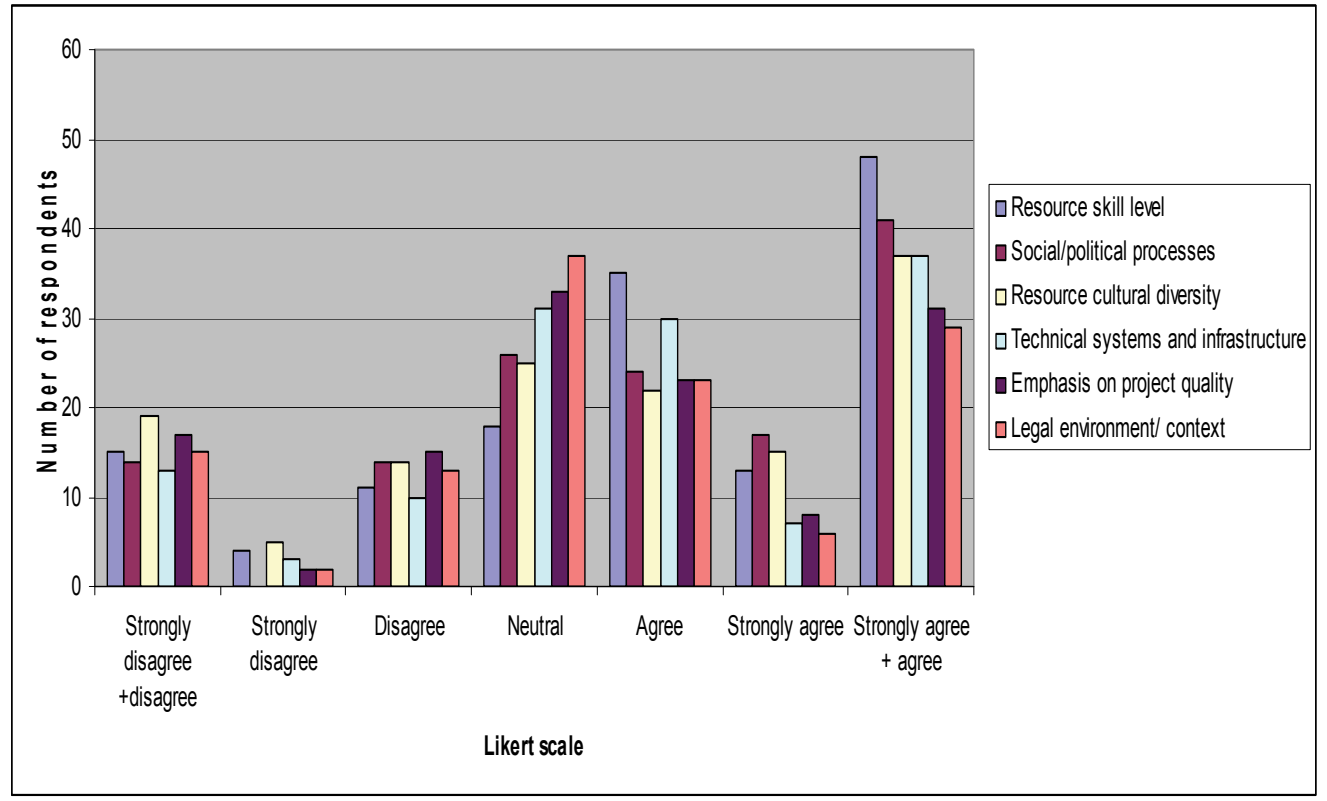

Figure 14: Factors that are different between RSA and international projects 


\section{CONCLUSIONS AND RECOMMENDATIONS}

The research objectives were met:

- Project perceptions in terms of project success, status reporting (whether pessimistic or optimistic), and the abandoning of projects before completion.

As regards perceptions of project success, internal stakeholders are more likely to have similar opinions on project success than external stakeholders. Project managers use optimistic reporting as they do not want to let the client, customer, team, or management down. Management perception and pressure does not seem to influence optimistic reporting behaviour. The research showed no consensus on the reasons for pessimistic reporting. The majority of projects in South African organisations are not abandoned before completion.

- $\quad$ Project management status in terms of whether project management processes and methods should change, and the most important success factors for projects.

The respondents agreed that the methods of project management in their organisations need to change. According to the respondents, the top five factors for achieving project success are teamwork, cost management, project planning, scope management, and leadership.

- $\quad$ Project measurement in terms of the importance of certain indicators for project success, and the use of evaluation tools in organisations.

The following were seen as being the six most important indicators of project success: client/customer satisfaction, project team skill level, senior management buy-in, communication or project reporting, problem scope management, and project delivery on time. The majority of South African organisations do not use project management evaluation tools.

- The South African context as it relates to the differences between international and South African project management practice.

This study did not show consensus on differences between South African and international projects. The only two factors that seemed slightly to differentiate South African from international projects were resource skill level and social/political processes.

In practice, these conclusions seem to indicate that South African organisations need to spend more time on managing external stakeholder perceptions of project success. As the use of project management evaluation tools was found to be low, organisations are encouraged to use these tools so that their project management practices are comparable with international best practice.

It is recommended that further research be conducted into the reasons for pessimistic project reporting. In the South African context, project management research is also required in teamwork, cost management, project planning, scope management, and leadership, as these are the most important factors identified for success. The difference between South African and international projects can also be explored further, especially in terms of different business sectors.

\section{REFERENCES}

[1] Widemann, R.M. 1995. Criteria for a project-management body of knowledge, International Journal of Project Management, Vol. 13, pp. 71-75.

[2] Andersen, E.S., Dyrhaug, Q.X. \& Jessen, S.A. 2002. Evaluation of Chinese projects and comparison with Norwegian projects, International Journal of Project Management, Vol. 20, pp. 601-609. 
[3] Belassi, W. \& Tukel, O.I. 1996. A new framework for determining critical success/failure factors in projects, International Journal of Project Management, Vol. 14(3) pp. 141-151.

[4] Standing, C., Guilfoyle, A., Lin, C. \& Love, P.E.D. 2006. The attribution of success and failure in IT projects, Industrial Management \& Data Systems, Vol. 106(8) pp. 1148-1165.

[5] Snow, A.P., Keiland, M. \& Wallace, L. 2007. The effects of optimistic and pessimistic biasing on software project status reporting, Information \& Management, Vol. 44, pp.,130-141.

[6] Yu, A.G., Flett, P.D. \& Bowers, J.A. 2005. Developing a value-centred proposal for assessing project success, International Journal of Project Management, Vol. 23, pp. 428-436.

[7] Cannon, J.A. 1994. Why IT applications succeed or fail. The interaction of technical and organisational factors, Industrial and Commercial Training, Vol. 26(1) pp. 10-15.

[8] Lyytinen, K. \& Hirschheim, R. 1987. Information systems failures: A survey and classification of empirical literature, Oxford Surveys in Information Technology, Vol. 4, pp. 257-309.

[9] Myers, M.D. \& Larsen, M.A. 1999. When success turns into failure: A package-driven business process re-engineering project in the financial services industry, Journal of Strategic Information Systems, Vol. 8, pp. 395-417.

[10] Pinto, J.K. \& Kharbanda, O.P. 1996. How to fail in project management (without really trying), Business Horizons, July/August, pp. 45-53.

[11] Pinto, K.J. \& Mantel, S.J. 1990. The causes of project failure, IEEE Transactions on Engineering Management, Vol. 37(4), pp. 269-276.

[12] Patanakul, P. \& Milosevic, D. 2005. Standardised project management may increase development projects success, International Journal of Project Management, Vol. 23, pp. 181-192.

[13] Winter, M. \& Smith, C.2006 Rethinking project management - final report, EPSRC Network 2004-2006. Retrieved from http://www.mace.manchester.ac.uk/project/ research/management/rethinkpm/final.htm

[14] Crawford, L., Pollack, J. \& England, D. 2006. Uncovering the trends in project management: Journal emphases over the last 10 years, International Journal of Project Management, Vol. 24, pp. 175-184.

[15] Slevin, D.P. \& Pinto, J.K. 1986. The project implementation profile: New tool for project managers, Project Management Journal, Vol. 18 pp. 57-71.

[16] Belout, A. 1998. Effects of human resource management on project effectiveness and success: Toward a new conceptual framework, International Journal of Project Management, Vol. 16(1), pp. 21-26.

[17] Project Management Institute. 2003. Organisational project management maturity model (OPM3), KnowledgeFoundation, Project Management Institute.

[18] Zwikael, O. \& Globerson, S. 2006. Benchmarking of project planning and success in selected industries, Benchmarking: An International Journal, Vol.13(6), pp. 688-700.

[19] Page, C. \& Meyer, D. 2003. Applied research design for business and management, $1^{\text {st }}$ edition, Macquarie Park, Australia, McGraw-Hill. 